GOSPODARKA SUROWCAMI MINERALNYMI - MINERAL RESOURCES MANAGEMENT

2017

Volume 33

Issue 4

Pages 45-62

DOI 10.1515/gospo-2017-0041

\title{
Depositional environment of Paleogen amber-bearing quartz-glauconite sands from Zdolbuniv (Rivne region, NW Ukraine): mineralogical and petrological evidences
}

\section{Introduction}

The tertiary amber-bearing sands from the Zdolbuniv chalk mine (Volhyn uplands, Ukraine) represents the sedimentary cycle usually assigned to the Paleogene period. Sediments deposited at the Pripyat palaeobasin (SW part of the East European Platform) attract the research interest due to their mineral constituents (amber grains, glauconite) which may be valuable from the economic point of view.

Specimens of amber originating from those clastic rocks were previously investigated by Engel and Perkovsky (2006) and also Ignatov and Perkovsky (2011), while petrographic interpretation of the sands was given by Stiepanjuk and Tutskij (1999) and Parańko et al. (2011). Krzowski (1995) using K-Ar method for dating glauconite grains stated the Paleogene origin of the amber-bearing sands from this region. However, it seems that some

* Faculty of Geology, Geophysics and Environmental Protection, AGH University of Science and

Technology, Krakow, Poland; e-mail: natkan@agh.edu.pl

** National University of Water and Environmental Engineering, Rivne, Ukraine

*** Polish Geological Institute - National Research Institute, Warsaw, Poland 
geological problems connected with transportation processes, depositional environments and an interpretation of clastic material provenience have not been discussed thorough in the literature, especially in the context of palaeogeography and correlation with Pripyat palaeobasin strata. Therefore, it was assumed that further mineralogical and petrological studies are needed for the reconstruction of the depositional history of those deposits. This paper provides an opportunity to verify the current stage of knowledge about sedimentation processes at the East European Platform. Moreover, it was believed that detailed analysis shed new light on the economic potential of these sediments.

To achieve this goal the samples of sands were investigated with a stereomicroscope, a polarizing microscope in transmitted light, scanning electron microscope (SEM) equipped with an energy-dispersive detector (EDS), cathodoluminescence (CL) and Raman micro-spectroscopy (RS) method. Special attention was given to the glauconite grains, as it is the main mineral constituent of economic interest.

\section{Geological setting}

Paleogene amber-bearing sediments in the Zdolbuniv chalk quarry are located in the Eastern part of the Volyn Upland, far from city of Rivne and the town of Zdolbuniv (Ukraine). They belong to the Pripyat sedimentation palaeobasin, which is the largest area of amber deposits in the southwestern part of East European Platform (Fig. 1A). At the geological map of Ukraine (sheet of M-35-XV) the Paleogene marls and quartz-glauconite sands of this region are classified to the Kievan system of middle Eocene (vide State Geological Map of Ukraine).The lower structural level of the site is presented by Vendian (Ediacaran) system stratons (Volyn, Mohyliv-Podilskyi, Kanylivka series) and Lower Cambrian, which are monoclinally inclined to the south-west (Czebanienko et al. 1990). The upper level thickness reaches up to 70 meters. It consists of chalk (Turonian-Coniacian), Paleogene sands (Eocene-Oligocene), Neogene sands (Lower Sarmatian) that lie horizontally. They are all covered by Quaternary loam cover.

Fig. 1. Localization and geological sketch map of the Zdolubniv quarry

A - Fragment of the geological map and cross-section of the Zdolbuniv town; 1-4 - Vend (Ediacaran): 1 - Volyn series; 2-3 - Mohyliv-Podilskyi series; 4 - Kanylivka series; 5 - Lower Cambrian;

6 - Turonian-Coniacian (Cretaceous); 7 - Eocene-Oligocene (glauconitic sands);

8 - Lower Sarmatian (sands); 9 - Upper Sarmatian (limestones); 10 - the quarry location.

$\mathrm{B}$ - Paleogene and Neogene sediments cross-section of the Zdolbuniv town in the chalk quarry (Rivne region)

Rys. 6. Kamieniołom Zdolubniv - lokalizacja na tle szkicu geologicznego

A - fragment mapy geologicznej oraz przekrój poprzeczny okolic miasta Zdolbuniv ; 1-4 - Vend (Ediacaran):

1 - seria Wołyńska; 2-3 - seria Mohylowsko-Podolska; 4 - seria Karliwska; 5 - dolny kambr;

6 - Turon-Koniar (kreda); 7 - eocen-oligocen (piaski glaukonitowe); 8 - dolny sarmat (piaski);

9 - górny sarmat (wapień); 10 - lokalizacja kamieniołomu. B - przekrój poprzeczny przez osady paleogenu

i neogenu odsłaniające się w kamieniołomie Zdolbuniv (okolice Rivnego) 

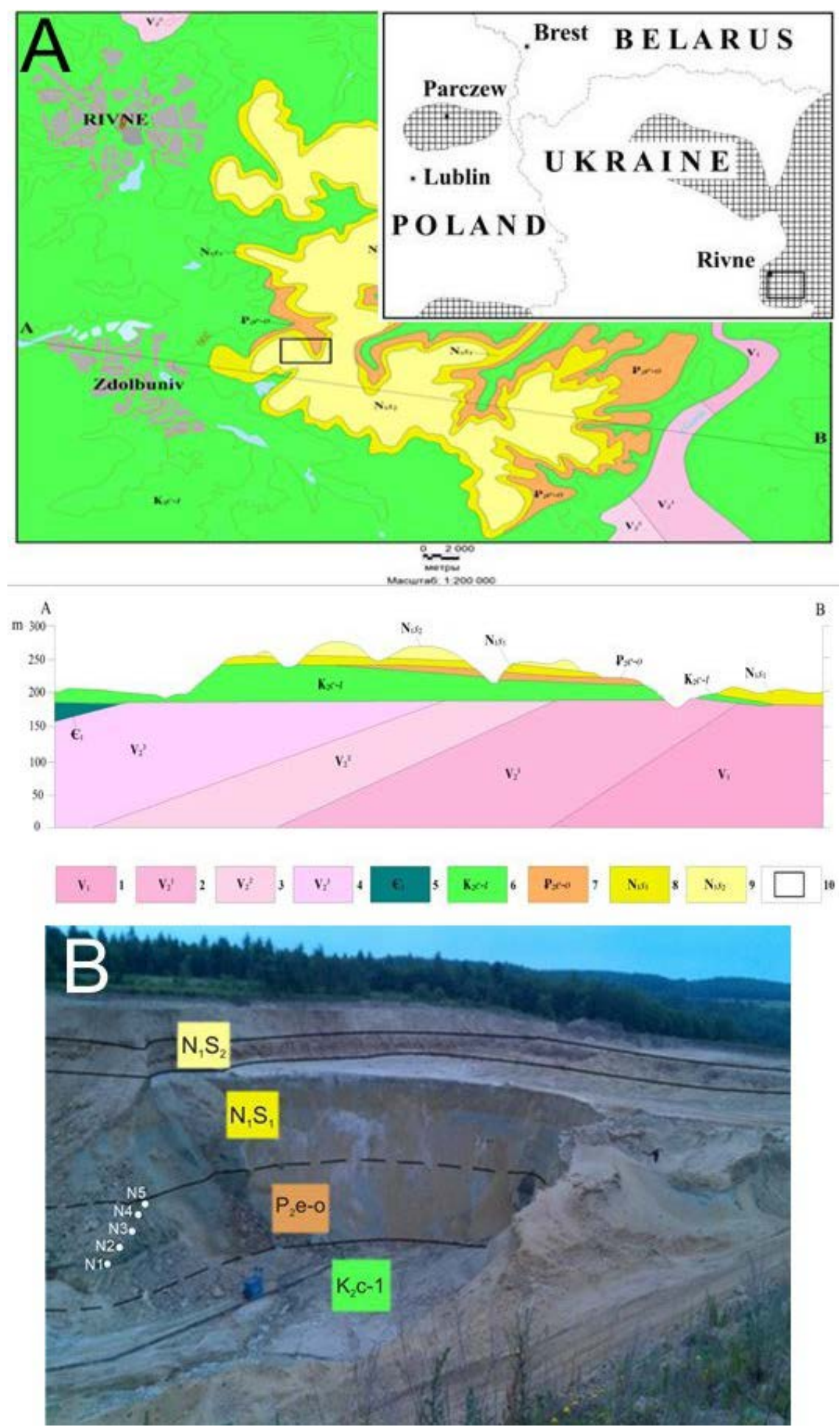
The green glauconitic Paleogene sands spread in the basis of resistant to erosion inlier located to the east of Rivne city and Zdolbuniv town. The Paleogene section, which is 7-10 meters thick (Fig. 1B) is uncovered in the chalk quarry, that is own by Dyckerhoff AG company (PAT Volyn-Cement), 5 kilometers east from the Zdolbuniv railway station. Paleogene sediments lie on Cretaceous rocks and are covered by Neogene layers in the eastern wall of the quarry (grey clay-quartz Lower Sarmatian sands 12-18 meters in thickness). Above them, polite-coquina limestones and Upper Sarmatian calcareous sandstones lie forming 3-5 meters thick zones. Calcareous yellowish-white aleurites (0.5-3.0 meters) are deposited in the lower part of Paleogene stratum. They contain fine (1-5 millimeters) debris, pebbles of black flints up to 10 centimeters and lenses (5-15 centimeters thick) of darkgrey clays with charred plant roots remnants. Upward aleuritic-psammitic material's content is significantly increasing. Their color changes to greenish-grey due to the presence of glauconite and mica. Grains of amber in sands of Paleogene from the Zdolbuniv chalk quarry have been identified first by the Ukrainian co-authors of the present work. The aleurites are identified as the Kyiv suite of Middle Eocene (age is proved based on study of Foraminifers). The upper part of Paleogene stratum is presented by green glauconite-quartz mostly fine-grained clay sands. They correlate with the Obukhiv suite of the Upper Eocene and Mezhygirya suite of the Lower Oligocene, which are distinctive for the Pripyat amber-bearing palaeobasin.

\section{Sampling and analytical methods}

The five samples (N1-N5) of amber-bearing sands for analysis were taken from the Zdolbuniv chalk quarry (Fig. 1B) at the depth 21-22 meters. N1 and N5 represent samples collected at the bottom to the top of the profile. They were examined with the stereomicroscope in order to select the proper material for the further research using the granulometric analyses, observations with polarizing microscope, the scanning electron microscope (SEM-EDS), cathodoluminescence (CL) and Raman micro-spectroscopy (RS) method. Microscopic observations, granulometric analyses and Raman micro-spectroscopy were carried out at the laboratories of the Faculty of Geology, Geophysics and Environmental Protection of AGH-The University of Science and Technology in Krakow (Poland). The cathodoluminescence analyses were made at the Polish Geological Institute - National Research Institute in Warsaw (Poland).

The stereomicroscope SNZ-168coupled with digital camera worked in magnifications range from $7,5 \times$ to $50 \times$, using Panasis software

All the samples were subjected to granulometric analyses. The sediments, weighting from 200 to $350 \mathrm{~g}$, were divided with a series of stainless steel sieves (of the dry) into five grain-size fractions, i.e. $>0.6,0.6-0.3,0.3-0.12,0.12-0.075$ and $<0.075 \mathrm{~mm}$.

The microscopic observations in the transmitted light of thin sections were made with a BA310POL polarizing microscope with a magnification range from $4 \times$ to $60 \times$. All the samples (N1-N5) were subjected to planimetric analysis (ca. 300 points of counts). 
Backscattered electron observations were performed on that polished sections using an FEI Quanta 200 field emission gun scanning electron microscope equipped with energy-dispersive spectroscopy. The system was operated at $20 \mathrm{kV}$ accelerating voltage in low-vacuum mode.

The cathodoluminescence analyses were conducted on polished thin sections using a Cambridge Image Technology CCL 8200 MK3 device (cold cathode) linked to a Nikon Optiphot 2 polarizing microscope.

The Raman spectra of heavy minerals were recorded using a Thermo Scientific DXR Raman microscope, equipped with $100 \times, 50 \times$ and $10 \times$ magnification objectives and an automatic " $\mathrm{x}-\mathrm{y}$ " table. The thin sections of sands were excited in room temperature with a $532 \mathrm{~nm}$ high-power argon laser, with focus diameter 1-2 $\mu \mathrm{m}$ and power of laser 10-20 mW. The spectra were corrected for background by method of sextic polynomial using Omnic software.

\section{Results}

\subsection{Stereomicroscope}

Generally all samples of the amber-bearing sands (N1-N5) are poorly sorted out and exhibit similar mineral composition of the granular components (Fig. 2). Sub-angular to sub-rounded quartz grains are the main component of the sediments. Glauconite, feldspars, mica, amber, lithoclasts and dark phases, being probably grains of heavy minerals occur subordinately.

\subsection{Microscopic observations and grain size distribution}

The sands exhibit variable structural and textural features as well as the size of the individual phase of minerals. The granulometric analysis showed a considerable contribution of the two grain-size fractions, i.e. $0.3-0.12$ and $0.6-0.3 \mathrm{~mm}$, which represent ca. $86-91 \mathrm{vol}$. \% of the analyzed material. Fractions smaller than $0.12 \mathrm{~mm}$ made up from ca. 11 to 2 vol. \% of the total sample mass, depending on the location of the collecting site. The samples show variable preservation degree of mineral components, some are fresh, whereas others are altered. As a result sericite and chlorite are locally formed after feldspars and mica, respectively. The textural characteristics and mineral composition of these sediments are shown in Figures 3-4:

N1 sample is moderately sorted out (Fig. 3). Its components show variable degree of roundness, from fine to low. Quartz grains, which are the most abundant in the sample, are often angular, elongated, and locally cracked. Apart from single quartz grains there are also quartz aggregates with mosaic structure. Glauconite grains are well rounded with variable sizes, the most often in the range from 0.1 to $0.25 \mathrm{~mm}$. White mica flakes without any traces 


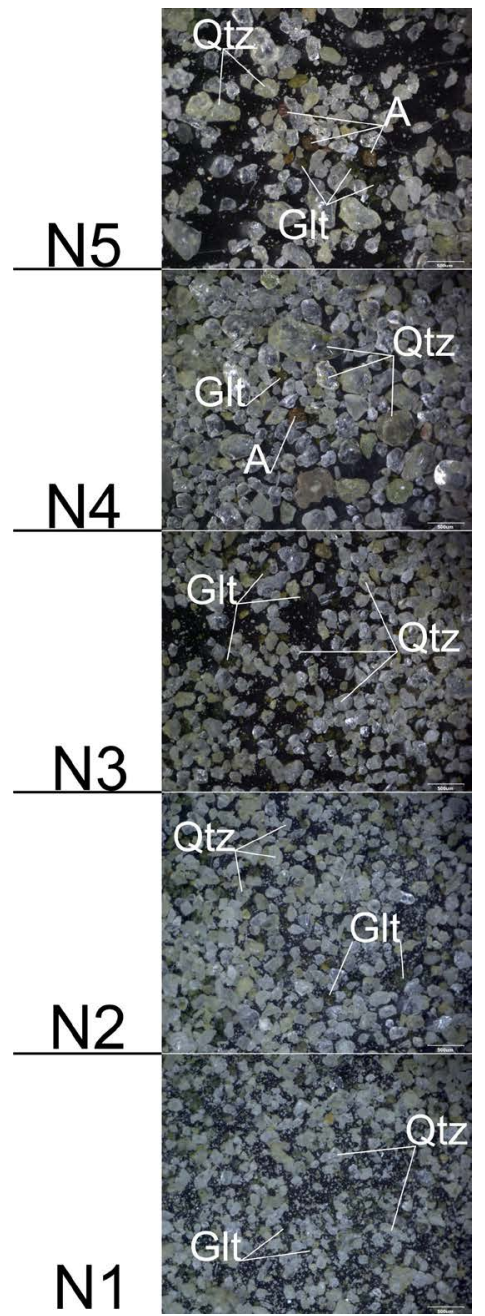

Fig. 2. Stereomicroscope's images of the amber-bearing sands (N1-N5) from the Zdolbuniv chalk quarry. Grain-size and mineralogical differentiation of that sediments from the bottom to the top of the profile can be observed.

Symbols: A - amber, Glt - glauconite, Qtz - quartz

Rys. 2. Obrazy z mikroskopu stereoskopowego piasków bursztynonośnych z kamieniołomu wapienia Zdolbuniv. Widoczne zróżnicowanie wielkości ziaren oraz składu mineralogicznego w górę profilu Oznaczenia: A - żywica kopalna, Glt - glaukonit, Qtz - kwarc

of weathering and strongly altered plagioclases also occur in the sample. Single grains of zircon and amber are found. Opaque minerals appear in traces.

- N2 sample is very similar to the N1 sample (Fig. 3). In its mineral composition quartz dominate over glauconite, mica and opaque minerals. The quartz grains are angular 


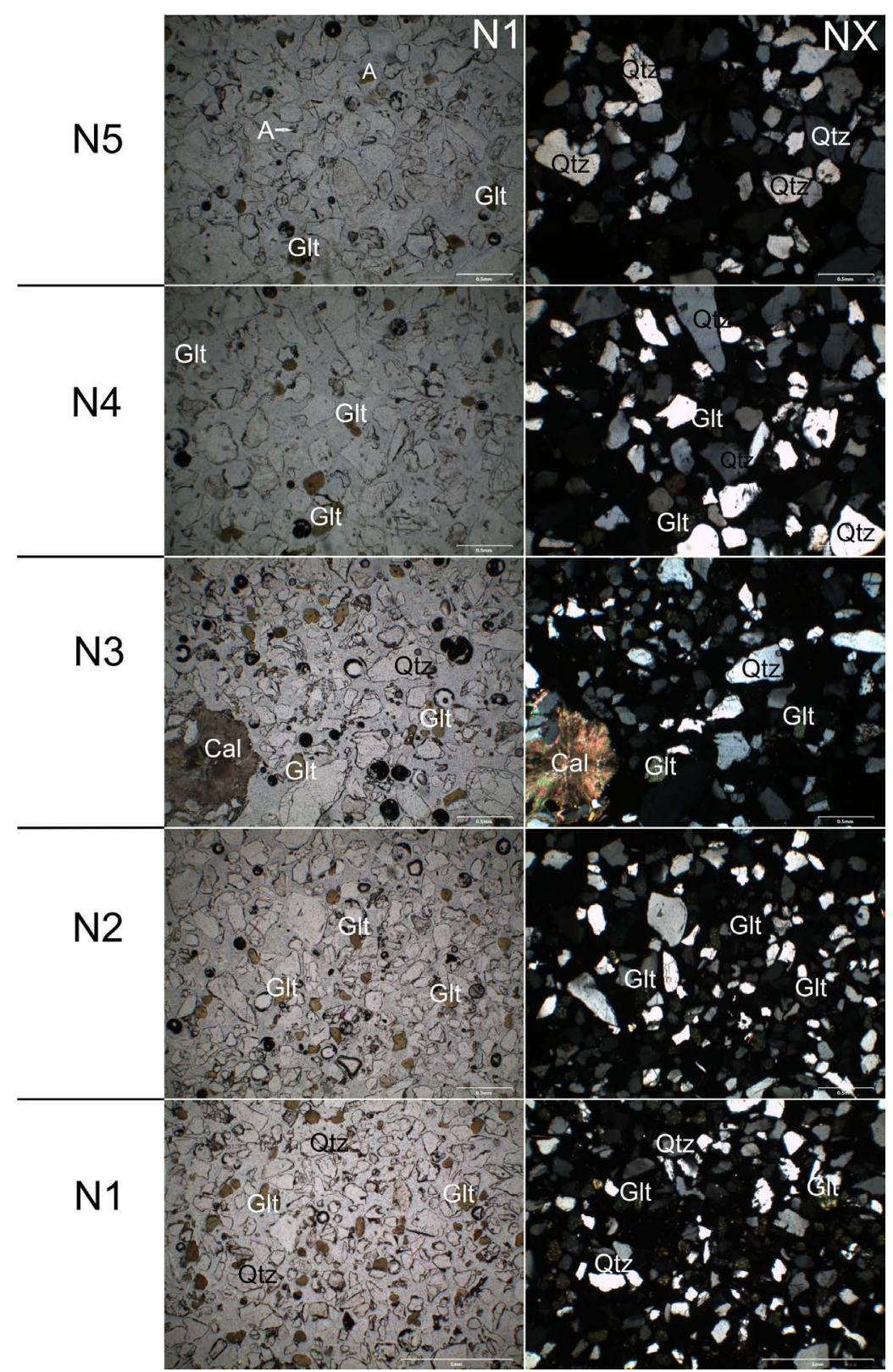

Fig. 3. Microscopic images (under transmitted light) of the amber-bearing sands (N1-N5) from the Zdolbuniv chalk quarry. Variability in textural features and mineral composition of analyzed samples of the profile can be observed.

Symbols: A - amber, Cal - calcite, Glt - glauconite, Qtz- quartz

Rys. 3. Obrazy mikroskopowe (światło przechodzące) piasków bursztynonośnych (N1-N5) $\mathrm{z}$ kamieniołomu Zdolbuniv.

Widoczne zróżnicowanie teksturalne oraz zmienny skład mineralogiczny osadów w badanym profilu Oznaczenia: A - żywica kopalna, Cal - kalcyt, Glt - glaukonit, Qtz - kwarc 


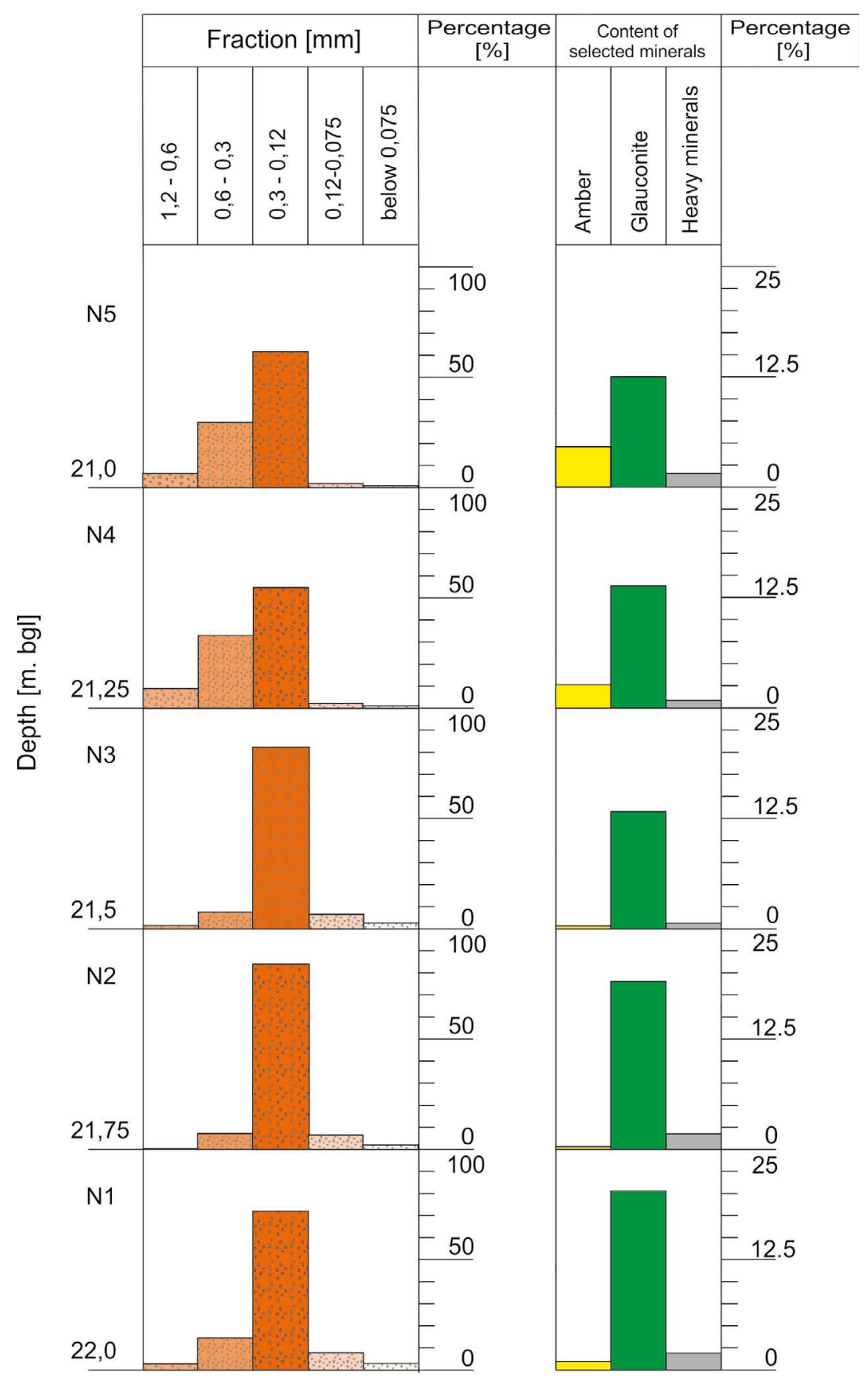

Fig. 4. Histogram illustrating the results of grain size analyzes of sands (N1-N5) from the Zdolbuniv chalk quarry

Rys. 4. Histogram prezentujący wyniki analiz granulometrycznych piasków (N1-N5) z kamieniołomu Zdolbuniv 
and sub-angular. Opaque minerals are mainly represented by hematite, which forms grains up to $2 \mathrm{~mm}$ in size. Single grains of carbonates are also observed in this sample.

- N3 sample-quartz predominates in the mineral composition (Fig. 3). Its grains exhibit higher degree of roundness, from sub-angular to sub-rounded. Inclusions of opaque minerals (rutile?) are found within individual grains of quartz. Apart from single quartz grains, quartz aggregates with mosaic structure are also found. The amount of glauconite seems to be relatively less than in N1 and N2 samples. Glauconite forms single grains (I generation) and fills the fissures within quartz grains or quartz mosaic aggregates (II generation). Single grains of mica, heavy minerals, carbonates and lithoclasts built of quartz (Fig. 4) appear as subordinate phases.

- N4 sample contains mineral components with good roundness degree from sub-rounded to well-rounded (Fig. 3). Quartz, the main component, forms two types of grains: i.e. numerous, large, rounded and strongly fractured and less abundant, smaller, sub-rounded. The second quantitative component is glauconite, which content is relatively less than in the samples taken from greater depths of the profile $(\mathrm{N} 1$, N2, N3). Here, similarly as in N3 sample, glauconite occur in the form of a single, isolated grains (I generation), and as inclusions in the quartz grains and polymineral aggregates (II generation). Single mica flakes, feldspars and zircon grains appear in traces. Opaque phases are smaller and less abundant than in samples N1-N3 (Fig. 4).

- N5 sample (Fig. 3) shows a strong resemblance for the N4 sample, both in textural characteristics and mineral composition. The dominant quartz grains are of different sizes and shapes, i.e. bigger and better rounded, while the smaller ones are clearly more angular. The other components, i.e. glauconite, microcline and mica are subordinate. For this sample the participation of opaque minerals, which form angular grains, is the smallest in the whole analyzed profile.

\subsection{Cathodoluminescence $(C L)$}

Cathodoluminescence (CL) observations indicated quartz, the dominant component of amber-bearing sands, forms single crystals, lithoclasts and single grains of multi-crystalline metamorphic quartz (Fig. 5). The majority of quartz crystals show brown CL colours. Quartz lithoclasts are mainly represented by metamorphic quartz schists and grains of multi-crystalline metamorphic quartz, which under transmitted light look nearly identical. Generally quartz grains have no regeneration rims, which could have been formed in the current clastic rocks. Locally there are quartz healed fractures and quartz regeneration rims occurring onto single, big grains.

The presence of feldspars, which make up ca. 5 vol. $\%$ of the amber-bearing sands, can be very well observed. K-feldspars with characteristic light blue CL colors predominate over plagioclases with green and yellow-brown CLluminescence. Some crystals of K-feldspars 


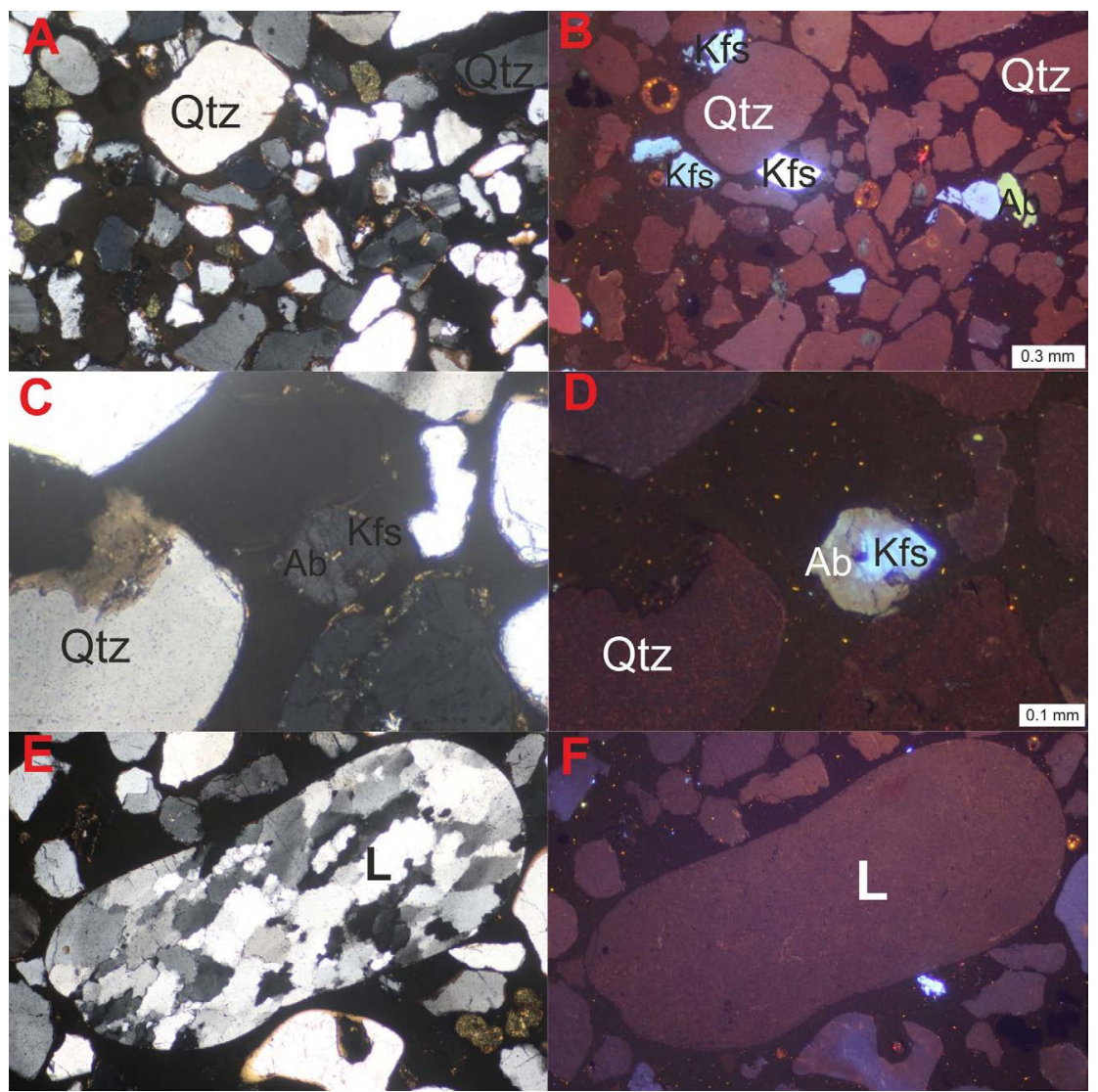

Fig. 5. Microphotographs of amber-bearing sands (N2 and N4),

A, C, E - polarized light; B, D, F - cathodoluminescence.

Symbols: Ab-albite, Kfs - K-feldspar, L - lithoclast, Qtz - quartz, Pl - plagioclase

Rys. 5. Mikrofotografie piasków bursztynonośnych (N2 oraz N4),

A, C, E - światło spolaryzowane; B, D, F - obraz katodoluminescencyjmy

Oznaczenia: Ab-albit, Kfs - skalenie potasowe, L - litoklasty, Qtz - kwarc, Pl - plagioklaz

were partially or totally albitized and exhibit light green CL color. Other alkaline feldspars show pink CL colors, produced by metasomatic processes (fenitization) (vide Kayama et al. 2010; Maki et al. 2016), with relics of primary feldspars having blue CL.

\subsection{Scanning electron microscopy (SEM-EDS)}

A scanning electron microscopic study (SEM) of all samples of amber-bearing sands from the Rivne region have been confirmed in earlier tests. EDS analyses made on a few glauconite grains coming from sands collected at various depth (N1-N5) revealed slight differences in their chemical composition (Fig. 6). In all samples two types of glauconite 

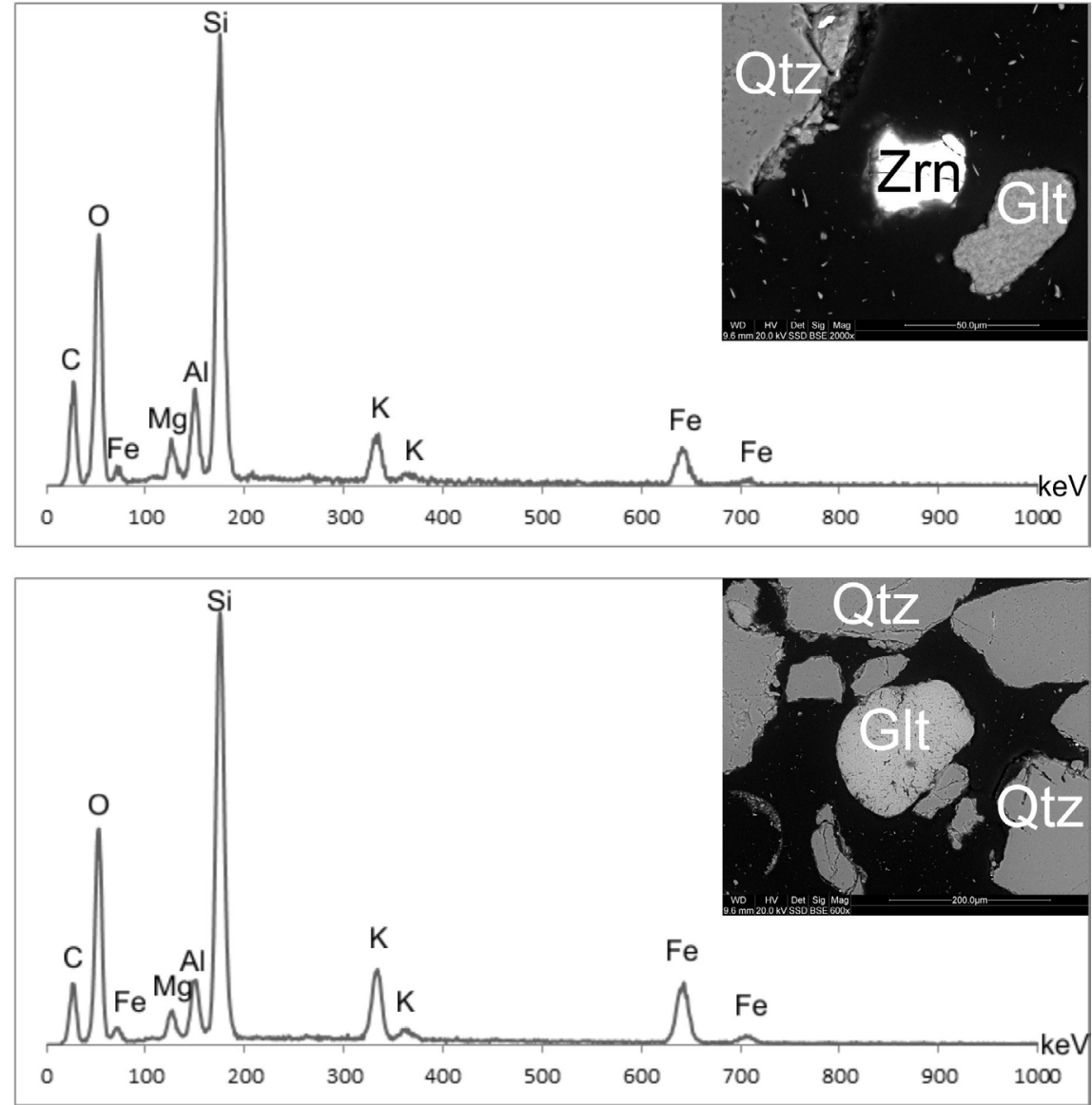

Fig. 6. EDS-spectra of various glauconite grains (A, B) from N4 sample. Symbols: Glt - glauconite, Qtz - quartz, Zrn - zircon

Rys. 6. Widma EDS ziarn glaukonitowych (A, B) pochodzących z próbki N4. Oznaczenia: Glt - glaukonit, Qtz - kwarc, Zrn - cyrkon

grains can be observed: i.e. ones enriched in Fe, whereas others contain less iron, which is substituted by $\mathrm{Al}$ and $\mathrm{Mg}$.

Underback-scattered (BSE) images show that the heavy minerals are mainly represented by zircon and ilmenite (Fig. 7). Zircon forms anhedral grains with sizes up to $30 \mu \mathrm{m}$. Manganese-bearing ilmenite is crystallized as tabular grains up to $100 \mu \mathrm{m}$. It contains traces of Mn. Among accessory phases epidote was also identified. It forms prismatic and elongated grains up to $120 \mu \mathrm{m}$ in length. 

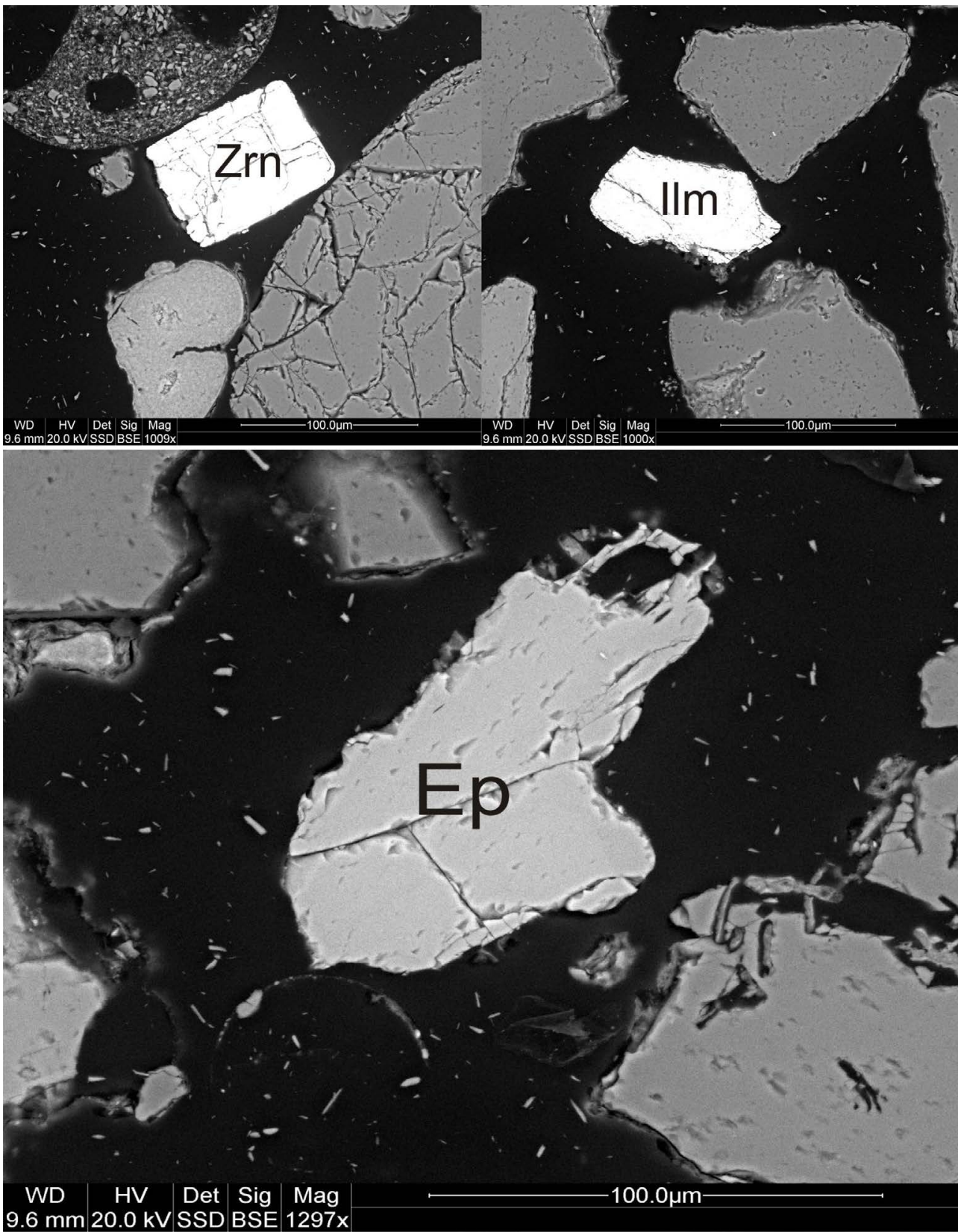

Fig. 7. BSE images of accessory components of amber-bearing sands (N1, N3, N5). Symbols: Ilm - ilmenite, Ep - epidote, Zrn - zircon

Rys. 7. Obrazowanie BSE składników akcesorycznych piasków bursztynonośnych (N1, N3, N5). Oznaczenia: Ilm - ilmenit, Ep - epidot, Zrn - cyrkon 


\subsection{Raman micro-spectroscopy}

Ti compounds (rutile and anatase), representing the numerous heavy minerals in all samples of amber-bearing sands were possible to be precisely identified only with Raman micro-spectroscopy method (Fig. 8). The marker bands of rutile appear at 609 and $441 \mathrm{~cm}^{-1}$, which correspond to $A_{1 g}$ and $E_{g}$ vibrational modes (Swamy and Muddle 2006). Whereas the bands at $636,514,393$ and $141 \mathrm{~cm}^{-1}$ are diagnostic of anatase. The two bands at 636 and $393 \mathrm{~cm}^{-1}$ are assigned to $\mathrm{B}_{1 \mathrm{~g}}$ modes (Balachandran and Eror 1982; Hardcastle 2011). The bands at 514 and $141 \mathrm{~cm}^{-1}$ are associated with $\mathrm{A}_{1 \mathrm{~g}}$ and $\mathrm{E}_{\mathrm{g}}$ modes, respectively (Balahandran and Eror 1982).
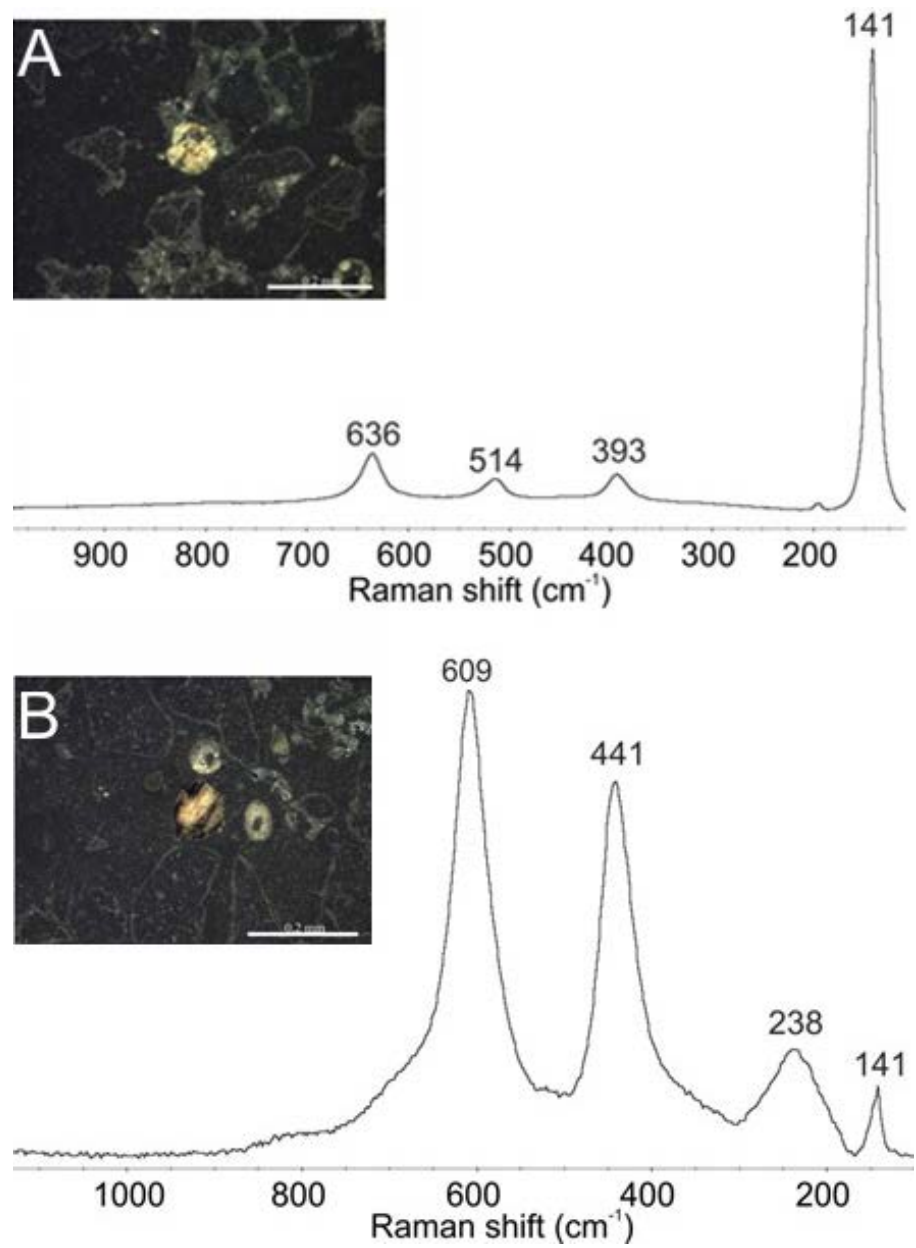

Fig. 8. Microphotos of anatase (A) and rutile (B) with their Raman spectra Rys. 8. Mikrofotografie anatazu (A) oraz rutulu (B) wraz z widmamia Ramana 


\section{Discussion}

The amber-bearing quartz-glauconite sands from Zdolbuniv mine (NW Ukraine) are Paleogene fine-grained $(0.6-0.12 \mathrm{~mm}$ in size) clastic rocks. They represent sediments of palaeobasin of Volyn Upland extending from Rivne city to the town Zdolbuniv, which belong to the south-western part of East European Platform (Fig. 1). The granulometric analysis showed that sands collected at the top of the profile $(\mathrm{N} 5, \mathrm{~N} 4)$ are relatively more coarsegrained then samples from the bottom. Generally they represents sediments of psammitic fractions with the grain-size of $0.3-0.12$ and $0.6-0.3 \mathrm{~mm}$, which make up ca. $86-91 \mathrm{vol} . \%$ of the material. The greenish color of that sediment results from a large amount of glauconite in it.

The microscopic observations revealed that the clastic material is poorly rounded and moderately sorted out (Fig. 2). The degree of preservations of minerals in various samples is also different. The quartz exhibit varying degrees of roundness: small grains, less than $0.08 \mathrm{~mm}$ in diameter, are always angular, while grains $>0.1 \mathrm{~mm}$ are well rounded. Generally, the degree of roundness of quartz grains is better for samples collected at the top than those from the bottom of the profile. Presumably the period and energy of the stream and eolian transport to the sedimentation basin was rather long and strong. Some quartz grains have a mosaic structure (Fig. 3). Locally they are cracked or exhibit regeneration rims, which together with host grains were rounded during transportation. Hence it is assumed the single regeneration rims were inherited from previous sedimentation cycle. Their presence could be connected with processes such as mechanical deformation and chemical activity.

The presence of glauconite in the amber-bearing sands is indicative of their marine origin (Pettitjohn et al. 1972; Dooley 2006). Its presence in all samples from the whole profile (Fig. 4) proves that sedimentation basin had to be marine reservoir, though gradually became shallower up to the littoral zone. It was observed that the amount of glauconite decreases from the bottom (N1) to the top (N5) of the profile. It could indicate that the sedimentation rate was changing from low to higher as glauconite is believed to be an indicator of slow depositionary processes (Huggett and Gale 1997). Additionally, some Estuarian type of sedimentation could locally occur, what inhibit the glauconite formation (Huggett and Gale 1997).

Moreover, the variable composition of glauconite as well as the occurrence of two forms of grains, i.e. single and isolated and forming inclusions within quartz could suggest that there are at least two generations of this mineral in this sediment. The chemical research revealed the presence of at least two varieties of glauconite grains having various contents of $\mathrm{Fe}, \mathrm{Al}$ and K. Hower and Thompson (1975) as well as Velde and Odin (1975) noted that older glauconite had the smaller predominance of $\mathrm{Al}$ over $\mathrm{Fe}$ and greater participation of $\mathrm{K}$. This observation well corresponds to our data, glauconite more enriched in Fe and depleted in $\mathrm{Al}$ also has a higher contents of $\mathrm{K}$ in its composition (Fig. 6). The EDS data obtained indicates the average maturity of glauconite, which proves the changing environmental conditions in the sedimentary basin (Słodkowska and Kasiński 2016). The not very intense and unclear 
green color of glauconite as well as the uneven and jagged surface of the grains could support this thesis. Pale green coloration of glauconite could also indicate the increase of water content in the mineral structure as well as the decrease of potassium content (Ehlmann et al. 1963).

The greatest portion of fossil resins (ca 4.6 vol.\%) was noted for the samples from the top of the profile (N5). Kasiński (2016) suggested that resins of Eocene trees were transported by the rivers as well as surface run-off to marine reservoir. As a result of interaction with salt water the resin was affected by diagenetic processes. Matuszewska (2010) confirmed the presence of Baltic amber in Paleogene sediments along the south coast of the Eocene sea. Kasiński (2016) noted that the occurrence of amber-bearing sediments could be associated with marine regression facies. However, in the consequence of the next transgression, resins were removed from primary deposits to younger sediments. It seems that the occurrence of amber in the fine-grained sands could be also connected with multiple erosion of amber-bearing sediments and redeposition as a result. At that time the sedimentation basin was on the territory of present south-east Poland and north-west Ukraine.

The inverse correlation between the distribution of amber and glauconite in the sands was observed. The amounts of glauconite tend to decrease from 20.3 vol. \% (N1) to $12.5 \mathrm{vol} . \%$ in N5 sample, which characterizes the top part of the horizon. Whereas the highest contribution of the amber (4.6 vol. \%) was noted in the upper part of the profile (N5), and lowest in the bottom part ( 0.3 vol. $\%-\mathrm{N} 2$ and N3). It is assumed that amber-enriched sands from the upper part of the profile could accumulate near estuary, whereas sediments more enriched in glauconite from the bottom of the profile were deposited within shelf. As a result the samples N1-N5 represent sediments from various part of the sedimentation basin. From economical point of view, the sands from the bottom of the profile are the most promising for the recovery of glauconite, whereas the exploration of fossil resins may be initiated from the top of the profile.

The heavy minerals are mainly represented by zircon, Ti- and Fe-compounds such as rutile, anatase, ilmenite (Fig. 7, 8). The maximum content of heavy minerals was noted for sample (N1) from the bottom part of the profile. In general, heavy minerals form very fine grains with different degree of roundness. The predominance of rutile and zircon, which are relatively resistant to weathering and transport, among heavy minerals, could indicate that material was redeposited or the transportation time was relatively long. Among accessory components of quartz-glauconite sands the presence of epidote and manganese ilmenite was also documented. Such heavy mineral assemblages may indicate that the clastic material of that basin could originate both from igneous or metamorphic rocks. However, under CL observations (Fig. 5) the vast majority of quartz grains show brown CL colors which are diagnostic of metamorphic rocks (Zinkernagel 1978). Hence it is assumed that amber-bearing quartz-glauconite sands are probably originated from metamorphic rocks of the crystalline Ukrainian Shield. Together with that clastic material the fragment of fossil resins from the Paleogene off-shore forests were transported to the sedimentatary basin. 


\section{Acknowledgements}

The reviewers and the native speaker are gratefully acknowledged for their comments on the manuscript and proofreading text, respectively.This work was financially supported by the AGH-The University of Science and Technology (Krakow, Poland), research project No 11.11.140.319.

\section{REFERENCES}

Balachandran, U. and Eror, N.G. 1982. Raman spectrum of titanium dioxide. Journal of Solid State Chemistry 42, pp. 276-282.

Czebanienko, I.I., Wiszniakow, I.B. and Wlasow, B.I. 1990. Volyn-Podole geotectonics (in Russian), pp. 244.

Dooley, J.H. 2006. Glauconite [In:] Baker, J.M., Kogel, J.E., Krukowski, S.T. and Triedi, N.C. Industrial Minerals and Rocks. Commodities, Markets and Uses. Ed. 7, Society for Mining, Metallurgy and Exploration, Inc., Littleton, pp. 494-504.

Ehlmann et al. 1963 - Ehlmann, A.J.. Hulings, N.C. and Glover, E.D. 1963. Stages of glauconite formation in modern foraminiferal sediments. Journal of Sedimentary Petrology 33(1), pp. 87-96.

Engel, M.S. and Perkovsky, E.E. 2006. An Eocene Bee in Rovno Amber, Ukraine (Hymenoptera: Megachilidae). American Museum Novitates, nr 3506. American Museum of Natural History, New York.

Hardcastle, F.D. 2011. Raman Spectroscopy of Titania $\left(\mathrm{TiO}_{2}\right)$. Nanotubular Water-Splitting Catalysts. Journal of the Arkansas Academy of Science 65, pp. 43-48.

Hower, J. and Thompson, G.R. 1975. The mineralogy of glauconite. Clays and Clay Minerals 23, pp. 291-293.

Huggett, J.M. and Gale, A.S. 1997. Petrology and palaeoenvironmental significance of glaucony in the Eocene succession at Whitecliff Bay, Hampshire Basin, UK. Journal of the Geological Society 154, pp. 897-912.

Ignatov, M.S. and Perkovsky, E.E. 2011. Mosses from Rovno Amber. Arctoa 20, pp. 1-18.

Kasiński, J.R. 2016. Złoża bursztynu północnej Lubelszczyzny - historia poznania, budowa geologiczna, perspektywy [In:] Gazda L. ed. Lubelski bursztyn. Wyd. Miasta Kraków, pp. 70-93.

Kayama et al. 2010 - Kayama, M., Nakano, S. and Nishido, H. 2010. Characteristics of emission in alkali feldspar: A new approach by using cathodoluminescence spectral deconvolution. American Mineralogist 95, pp. $1783-1795$

Krzowski, Z. 1995. Glaukonit z osadów trzeciorzędowych regionu lubelskiego i możliwości jego wykorzystania do analiz geochronologicznych. Lublin: Wyd. Uczelniane Politechniki Lubelskiej.

Maki et al. 2016 - Maki, S., Ohgo, S. and Nishido, H. 2016. Cathodoluminescence characterization of feldspar minerals from granite-syenite rocks in Iwagijima Island, Ehime Prefecture, Japan. Naturalistae 20, pp. 13-18.

Matuszewska, A.L. 2010. Amber (succinite), another fossil, subfossil and modern resins. Katowice: Uniwersytet Śląski i Oficyna Wydawnicza W. Walasek (in Polish).

Parańko, I., Pieczonka, J. and Piestrzyński, A. 2011. Geologia wybranych złóż surowców mineralnych Ukrainy. Kraków: Wyd. AGH, pp. 37-58.

Pettitjohn et al. 1972 - Pettitjohn, F.J., Potter, P.E. and Siever, R. 1972. Sand and Sandstone. Ed.1, Springer - Verlag, Berlin, Heidelberg, New York, pp. 272-231.

Słodkowska, B. and Kasiński, J.R. 2016. Uwarunkowania klimatyczne i środowiskowe powstania złóż bursztynu bałtyckiego [In:] Gazda L. ed. Lubelski bursztyn. Wyd. Miasta Kraków, pp. 21-41

State Geological Map of Ukraine, scale 1:200 000 (sheet of M-35-XV). [Online] Available at: www.geoappl.kiev.ua:8888/reports/rwservlet?us\&report=kartogr\&list=m35-15 [Accessed: 4 April 2017]

Stiepanjuk, L. and Tutskij, W. 1999. Geologie und Mineralogie des Bernsteins von Klessow [In:] Kosmowska-Ceranowicz, B. and Paner, H. ed. Investigation into Amber. Gdańsk: Muzeum Archeologiczne w Gdańsku, pp. 53-60.

Swamy, V. and Muddle, B.C. 2006. Size-dependent modifications of the Raman spectrum of rutile TiO 2 . Applied Physics Letters 89. 
Velde, B. and Odin, G.S. 1975. Further information related to the origin of glauconite. Clays and Clay Minerals 23, pp. 376-381.

Zinkernagel, U. 1978. Cathodoluminescence of quartz and its application to sandstone petrology. Contributions to Sedimentary Geology 8.

\title{
ŚRODOWISKO DEPOYZCJI PALEOGEŃSKICH KWARCOWO-GLAUKONITOWYCH PIASKÓW BURSZTYNONOŚNYCH Z KOPALNI ZDOLBUNIY (OBWÓD ROWIEŃSKI, NW UKRAINA) W ŚWIETLE BADAŃ MINERALOGICZNO-PETROLOGICZNYCH
}

\author{
Słowa kluczowe
}

piaski bursztynonośne, obwód Równe, miasto Zdolbuniv, Ukraina

\section{Streszczenie}

Piaski bursztynonośne z kopalni Zdolbuniv (obwód rowieński, NW Ukraina) to paleogeńskie, drobnoziarniste $(0,6-0,12 \mathrm{~mm})$ skały klastyczne. Materiał ziarnisty tych piasków jest słabo obtoczony i średnio wysortowany. Stanowią go głównie kwarc i glaukonit oraz występujące w podrzędnych ilościach: skalenie (K-skalenie i plagioklazy), miki, węglany, cyrkon, epidot, żywice kopalne (bursztyn) i minerały rudne, takie jak: hematyt, rutyl, anataz, ilmenit. Obecność glaukonitu wskazuje na środowisko morskie sedymentacji tego materiału. Duże zróżnicowanie składu chemicznego poszczególnych osobników glaukonitu sugeruje, że w trakcie sedymentacji materiału ziarnowego dochodziło do zmian warunków środowiskowych w samym basenie. Obecność w przedmiotowych piaskach takich minerałów, jak np. cyrkon, epidot, ilmenit, rutyl, anataz, jak i barwy ziaren kwarcu na obrazach CL wskazują, że większość materiału ziarnowego pochodzi ze skał metamorficznych, najprawdopodobniej budujących podłoże Tarczy Ukraińskiej. Wraz ze wspomnianym materiałem do basenu sedymentacyjnego mogły być transportowane fragmenty paleogeńskiej żywicy (bursztynu), pochodzące z pobliskich lasów. Analizowany profil piasków jest w dolnej części wzbogacony w glaukonit, podczas gdy górna jego część jest wzbogacona we fragmenty żywic kopalnych.

DEPOSITIONAL ENVIRONMENT OF PALEOGEN AMBER-BEARING QUARTZ-GLAUCONITE SANDS FROM ZDOLBUNIV (RIVNE REGION, NW UKRAINE): MINERALOGICAL AND PETROLOGICAL EVIDENCES

\section{Keywords}

amber-bearing sands, Rivne region, Zdolbuniv town, Ukraine

\section{Abstract}

Amber-bearing sands from Zdolbuniv mine are Paleogene fine-grained $(0.6-0.12 \mathrm{~mm})$ clastic rocks. The material is poorly rounded and moderately sorted out. It mainly consists of quartz, glauconite, and subordinately, feldspars (K-feldspars and plagioclases), mica, carbonates, zircon, epidote, 
fossil resins (Baltic amber) and ore minerals such as hematite, rutile, anatase, ilmenite. The presence of glauconite in the sands proves that sedimentation basin had to be marine reservoir. The variable composition of individual glauconite grains suggests the environmental conditions had to change during the sedimentation of clastic rocks. The occurrence of minerals, assembly such as zircon, epidote, ilmenite, rutile, anatase in the sands as well as the brown CL color of quartz grains, may suggest that majority of clastic material originated from metamorphic rocks, most probably coming from the Ukrainian Shield. Together with metamorphic material the fragment of fossil resins, i.e. Baltic amber, from the Paleogene off-shore forests could be transported to the sedimentation basin. Nowadays the bottom part of the analyzed profile is the most promising for the recovery of glauconite, whereas the exploration of Baltic amber may be initiated from the top of the profile. 